Esta obra está bajo una Licencia Creative Commons Atribución-NoComercial-Compartirlgual 4.0 Internacional

(c) (1) (8) ()

Notas sobre religión, especismo y personalidad legal

Gonzalo Perez Pejcic y Pablo Suárez

DOI: https://doi.org/10.24215/16696581e232

\title{
Notas sobre religión, especismo y personalidad legal
}

\section{Some notes on religion, speciesism and legal personhood}

\section{Gonzalo Perez Pejcic gonzaloperezpejcic@gmail.com}

http://orcid.org/0000-0002-9853-8014

Instituto de Derecho Animal; Colegio de Abogados de San Martín/ Universidad de Buenos Aires/ Universidad Nacional de Avellaneda/ Universidad Austral (Argentina)

\section{Pablo Suárez psuarez@derecho.uba.ar \\ http://orcid.org/0000-0001-6697-3102}

Facultad de Derecho y Ciencias Sociales; Universidad de Buenos Aires/ Universidad de

Palermo (Argentina)

\section{Resumen}

Nuestro objetivo es intentar mostrar que existe una línea de continuidad disimulada pero poderosa entre algunas de las ideas más centrales y nocivas de las religiones judeo-cristianas y el humanismo antropocéntrico. Ello, con el fin de advertir cómo esta genealogía, que da lugar 
a la afirmación de una excepcionalidad-superioridad del ser humano, incide decisivamente en la concepción y atribución de personalidad jurídica. A partir de dicho diagnóstico, propondremos un primer esbozo de reconstrucción de la personalidad desde una mirada antiespecista.

Palabras clave: religion; especismo; persona; antropocentrismo; animales.

\section{Abstract}

Our aim is to try to show that it exists a hidden but strong continuity between some of the most essential and pernicious ideas of the judeo-christian religions and anthropocentric humanism. This, in order to convey how this genealogy, that affirms a human exceptionality-supremacy, contributes in a decisive way in the conception and awarding of legal personhood. From that, we will put forward a first draft of reconstruction of personhood from an anti-speciesist perspective.

Keywords: religion; speciesism; person; anthropocentrism; animals

\section{La persona para el humanismo antropocéntrico}

En países -como Argentina- en los cuales una parte mayoritaria de la población es bautizada al nacer y luego educada en sus primeros años en la religión Católica (1), el Antiguo Testamento de la Biblia es un libro que circula en la mayoría de los hogares y puede encontrarse en gran parte de las mesas de luz de niñas y niños. Se trata de un libro que por lo general nos regalan abuelas y padrinos, tiene tapas duras y gran tamaño, está lleno de historias y dibujos con mucho rosa, celeste y blanco, y que además de estudiarse en Catequesis se lee a la hora de dormir, ingresando esos relatos y moralejas a nuestros sueños, formando finalmente los mismos nuestros primeros valores. Allí se encuentra la historia de todo lo que pasó, la anticipación de todo lo que sucederá, el mandato de todo lo que debe hacerse y no hacerse; en suma, allí -se pretende- puede hallarse la explicación de todo.

Si necesitáramos resumir mucho, seguramente habría que concluir que la enseñanza central del Antiguo Testamento consiste en que la caída del hombre, esto es la más terrible pérdida que sufre la humanidad, la de una vida eterna, abundante y paradisíaca, tiene tres responsables (y un inocente): una planta, un animal y una mujer. (Una planta, que es una cosa; un animal, que desde ese momento inicial se decretó que sería una cosa; y una mujer, que 
sería también una cosa desde el inicio, desde el Génesis.) Como comienza a verse, ya desde el comienzo este texto divino, el libro más importante e influyente de toda la historia de la cultura judeo-cristiana, señaló y separó a sujetos de objetos, construyendo la identidad de los primeros a partir de la inferioridad y anormalidad de los segundos.

Luego, nos enseña el "Libro" que este hombre y esta mujer, Adán y Eva, tuvieron hijos; muchos hijos, al punto que los distintos autores e intérpretes no acuerdan en el número. Pero conocemos bien a los dos primeros: Caín y Abel. Uno era cazador, viril, carnívoro y ofrecía sacrificios animales a su padre celestial, mientras que el otro era agricultor y vegetariano. ¿Cuál era el preferido de Dios y cuál se convierte en el villano de la historia? Esta preferencia por Abel, por quien caza y sacrifica animales -que debían ser animales jóvenes y "sin defecto" (Levítico 9:2; Levítico 23:18; Ezequiel 46:13-15)- se vincula con otra admonición divina: "Ellos someterán al pez del mar, al ave de los cielos, a la bestia, a toda la tierra [...]. Fructificad, multiplicaos, llenad la tierra, conquistadla" (Génesis 1:28). El mandato es claro: conquista, colonización y dominación; no convivencia en hermandad.

Finalmente, el Decálogo, los Mandamientos. Las distintas versiones de los Mandamientos que contiene el Antiguo Testamento tienen una estructura similar. Inicialmente un grupo de mandamientos principales que se vinculan con la relación de Dios y su rebaño, donde se dice reiterativa y hasta redundantemente que él es el único dios, que no pueden idolatrarse otros dioses ni adorarse imágenes, que se lo celebrará y no se tomará su nombre en vano, entre otras admoniciones en esa misma línea. Seguido, un segundo grupo de mandamientos "morales", donde se prohíbe el asesinato -no todo asesinato (2)-, el robo, el falso testimonio, y finalmente se legisla (criminalizando el pensamiento) sobre el hombre y sus pertenencias, su patrimonio: su asno, su buey, su casa, su siervo, su mujer. Dice la versión del Deuterónimo de este último mandamiento: "No codiciarás la mujer de tu prójimo, ni desearás la casa de tu prójimo, ni su tierra, ni su siervo, ni su sierva, ni su buey, ni su asno, ni cosa alguna de tu prójimo". Nuevamente: sujetos y objetos.

Podemos enfrentarnos a estos famosos pasajes del Antiguo Testamento pensando que es algo del pasado, que luego de quince siglos de oscuridad y dogma, con la Edad Moderna (S. XV) se dejó atrás a la Edad Media, y la luz y la razón prevalecieron finalmente. Pero no. Queremos sugerir que algunas de las miradas más arraigadas y perniciosas del Teocentrismo se cuelan en el paradigma que lo sustituye, el Antropocentrismo -y de allí en el Renacimiento, el lluminismo y finalmente en el Humanismo antropocéntrico-, pero que además lo hacen a escondidas, a partir de un giro aparentemente superador. 
El juicio a Galileo, ocurrido en el año 1633 -luego de casi doscientos años de comenzada la Edad Moderna, y no en la Edad Media-, lo muestra con elocuencia. En ese tristemente famoso proceso, los valores y sobre todo el sesgo del paradigma teocéntrico -la idea de que Dios es el origen, motivo, explicación y fin de todo-, hicieron que lo que estaba escrito en esos textos viejos y apócrifos prevaleciera sobre lo que mostraban los telescopios y las matemáticas (Copérnico). Es así como quince siglos después el Antiguo Testamento continuaba teniendo preeminencia sobre la observación y el razonamiento científico, pues era palabra santa, que decía: "Y el sol se detuvo, y la luna se paró" (Josué 10:12). Y si Dios detuvo el movimiento del sol, lo cual no estaba sometido a debate, entonces era el sol el que se movía, girando, naturalmente, alrededor de la tierra. ¿Podemos desconocer la fuerza de estos poderosos sesgos?

La mirada crítica que proponemos sugiere que humanismo antropocéntrico no es mucho menos problemático que el Teocentrismo, pues, en definitiva, ¿quién pasó a ocupar el lugar de Dios como motivo, razón y fin de todo? Antropos: el hombre. ¿Y quién era este hombre? ¿Todos los hombres, todos los humanos, cualquiera de ellos? Claramente no. El "hombre" era el "Hombre de Vitruvio" que inmortalizó Leonardo Da Vinci en su célebre dibujo que lleva ese nombre (Braidotti, 2013, pp. 13-14). El "hombre" era el macho, blanco, propietario, hábil (no discapacitado), cis, heterosexual, cristiano y europeo (no sujeto a deportación). Ni la imagen de Leonardo ni el nombre del famoso dibujo dan lugar a dudas: la imagen encarna una particular idea de perfección, que además había sido explicitada en sus notas por el escritor, arquitecto e ingeniero romano Vitruvio (70-25 a. C.), quien había teorizado sobre la perfección física y racial. Leonardo abundaría sobre la normatividad de la perfección física que se podía encontrar en las proporciones de cada parte del cuerpo (ideal) respecto del todo (ideal).

¿Cómo este Hombre que se ubicaba en el lugar de Dios iba a ser menos racista, sexista, homofóbico, imperialista, genocida y supremacista que su padre celestial, que en el Antiguo Testamento mostró todos estos rasgos? (3) Por necesidad lógica: si el hombre se coloca en el lugar de Dios, y tiene la pretensión delirante de ser el centro y razón de todo, se comportará del mismo modo, como un tirano que elabora su identidad y traza diferencias a partir de la noción de superioridad.

Por ello, bien se señala que el humanismo antropocéntrico es colonialista, racista, logocéntrico, androcéntrico, generocéntrico y capacitista. Pero también, y no en último lugar, es especista. De hecho, una de las formas en las que este hombre del humanismo, este hombre supremacista, armó su identidad, fue afirmando una inferioridad de los demás que era una animalidad. Así, los habitantes originarios de América fueron exhibidos en Europa como animales y marcados como animales por la Iglesia Católica, por carecer, al igual que los 
animales, de alma (4). Las mujeres fueron (y son) animalizadas también (Adams, 2016). Las personas con discapacidades fueron exhibidas en la Inglaterra Victoriana, al igual que las mujeres africanas (el tristemente famoso caso de La Belle Hottentot), como animales, y luego la ciencia del Siglo XIX legitimó esa práctica al rotular sus condiciones con referencias a una inferioridad animal: Elefantiasis, Síndrome de garra de simio, Síndrome de garra de langosta, Pecho de paloma, Pie equino (Taylor, 2011, pp. 192-193).

De este modo, "Animal" no son sólo los cientos de millones de animales que cada año son encerrados, torturados y asesinados (por los motivos más banales, además). "Animal" también es una metáfora de inhábil, de anormal, de monstruo.

\title{
La persona para el derecho
}

Coincidente con el apartado previo, toda la teoría jurídica clásica niega a los demás animales el carácter de personas legales, considerando que sólo los integrantes de la especie Homo sapiens pueden ostentarlo, quienes además serían por "naturaleza" personas para el Derecho. Esta correlación de aparente sinonimia entre los términos "persona" y "humano" explica por qué normas como el Código Civil y Comercial de la Nación Argentina (en adelante: CCyC), a diferencia del anterior Código Civil de Dalmacio Vélez Sarsfield (en adelante: CC), no incluye una definición legal de persona (5). Y es que, en este punto el CCyC sigue a su fuente, el "Proyecto de Código Civil" del año 1998, en cuyos fundamentos los legisladores advirtieron que sólo se habían previsto definiciones en aquellos casos donde era necesario hacerlo. Así, entendieron que no era imprescindible contar con un concepto de persona, por cuanto:

\begin{abstract}
La noción de persona proviene de la naturaleza; es persona todo ser humano, por el solo hecho de serlo; y la definición de la persona a partir de su capacidad de derecho confunde al sujeto con uno de sus atributos, amén de que da la falsa idea de que la personalidad del sujeto es concedida por el ordenamiento jurídico. La idea del Proyecto es por el contrario que la persona es un concepto anterior a la ley; el Derecho se hace para la persona que constituye su centro y su fin. (Proyecto de Código Civil de la República Argentina, 1999, p.
\end{abstract} 16)

Refuerza esta creencia la opinión de los comentaristas al CCyC, quienes no piensan que sea un desacierto la falta de una definición de lo que es ser persona en el ámbito del Derecho, porque en rigor:

se trata de una noción que proviene de la naturaleza y es anterior a la ley. Más aun, la terminología adoptada [...] es suficientemente caracterizadora: es la calidad de 'ser 
humano' lo que determina la condición de 'persona humana' para el derecho. Así, no podría investir esta calidad quien no es un ser humano ni tampoco dejar de tener esta condición quien lo es. (Tobías, 2016, t. I, p. 160)

Por otra parte, mientras el CC empleaba la expresión persona "física", "natural" o "visible", para distinguir la personalidad del humano de aquella de la que gozaban los "entes ideales" (ej. sociedades comerciales, asociaciones civiles, fundaciones, etc.), el CCyC, utiliza la locución persona "humana". Modificación que se ha justificado de la siguiente manera:

\footnotetext{
La denominación 'persona física' parecía ser concordante con la limitación de sus alcances a lo meramente corporal y resultaba excluyente de los contenidos espirituales.

En cambio, la denominación 'persona humana' no olvida la naturaleza material, pero no descarta que paralelamente exista la dimensión espiritual, aunque tampoco la impone, pues acaso algunos se inclinen por reducir a la persona humana a tan solo la materialidad de lo físico. (Alterini y Alterini, 2016, t. I, pp. 160-161)
}

Sostenemos que esta equivalencia que afirman las normas y los comentaristas jurídicos entre persona y ser humano -lo cual supone por definición la negación de la personería para los demás animales, y de allí que gocen de un núcleo básico de protección jurídica-, se debe a una actitud especista que tiene origen finalmente en valores e ideas acerca de la persona propias de las religiones judeo-cristianas que permearon de modo soterrado en el humanismo antropocéntrico.

A continuación, seguiremos insistiendo sobre estas conexiones, para en un apartado final proponer la necesidad de reconstruir el significado legal de persona desde una posición antiespecista.

\section{El significado teológico de la voz persona}

En el contexto teológico la palabra persona se emplea no sólo para designar a los miembros de la especie Homo sapiens, sino también para hacer alusión a seres divinos.

\section{Personas divinas.}

La referencia a seres divinos aparece en el marco de los principales misterios de la fe cristiana: la santísima trinidad y la encarnación. 
El primer dogma sostiene que en la unidad de la divinidad hay tres personas, verdaderamente distintas una de las otras: el Padre, el Hijo y el Espíritu Santo. Al respecto, Agustín de Hipona, en su obra "De Trinitate" señala: “...decimos que el Padre es Dios, el Hijo es Dios y el Espíritu Santo es Dios, y nadie duda que Dios sea substancia; sin embargo, no hay tres dioses, sino un solo Dios, que es la Trinidad excelsa" (Agustín de Hipona, 1956, t. V, p. 411).

Así, la palabra persona se ha utilizado para esclarecer las relaciones trinitarias, especialmente la posición de Dios hijo respecto de Dios padre, tema que generó profundos debates a lo largo de la historia y que se supera, principalmente, en el Concilio de Nicea del año $325 \mathrm{dc}$, donde se asevera que Dios es una sola sustancia (o naturaleza) y que, en él, se distinguen tres personas. De ahí que el hijo no se encuentra subordinado al padre, ya que es consubstancial a él (comparten igual sustrato divino) (6).

Por otra parte, el término también se ha empleado para dilucidar la naturaleza de Dios hijo en sí mismo, ya no en relación al Padre. Sin embargo, al igual que sucedió con los debates trinitarios, largos fueron los cruces en este tema, porque existían quienes afirmaban que: (1) en Cristo el Verbo había sustituido al alma o espíritu, negando entonces que el hijo haya asumido un alma racional humana (apolinarismo); (2) la naturaleza humana había dejado de existir como tal en Cristo al ser asumida por su persona divina de hijo de Dios (monofisismo o eutiquianismo); y (3) en Cristo se veía una persona humana junto a la persona divina del hijo de Dios (nestorianismo) (Catecismo de la Iglesia Católica, 2015, n 464-478).

Dadas las distintas posiciones, el Concilio ecuménico de Calcedonia del año 451 dc declaró que en Cristo las dos conservan sus propias características, pero unidas en una persona, por lo que éstas no se encontraban unidas de manera accidental (como prescribía el nestorianismo) ni mezcladas (como defendía el eutaquianismo) (Pace, 1910). En este sentido, la expresión teológica "unión hipostática" se utiliza a los fines de expresar: "...la verdad revelada de que en Cristo una persona subsiste en dos naturalezas, la Divina y la humana" (Pace, 1910).

A la vista de esta explicación, se comprenden las enseñanzas plasmadas en el Catecismo cuando en alusión a la Encarnación -el hecho de que el hijo de Dios haya tomado naturaleza humana para llevar a cabo la salvación-, se asevera:

El acontecimiento único y totalmente singular de la Encarnación del Hijo de Dios no significa que Jesucristo sea en parte Dios y en parte hombre, ni que sea el resultado de una mezcla confusa entre lo divino y lo humano. Él se hizo verdaderamente hombre sin dejar de ser verdaderamente Dios. Jesucristo es verdadero Dios y verdadero hombre. (Catecismo de la Iglesia Católica, 2015, n 464)

Question, Vol. 1, N. ${ }^{\circ}$ 64, octubre-diciembre 2019. ISSN 1669-6581

Instituto de Investigaciones en Comunicación | Facultad de Periodismo y Comunicación Social | Universidad Nacional de La Plata La Plata | Buenos Aires | Argentina

Página 7 de 18 


\section{Personas humanas}

El cristianismo afirma que las dos naturalezas del ser humano se unen en un nivel de profundidad tal que, de su conexión, deriva la persona humana: "La persona humana, creada a imagen de Dios, es un ser a la vez corporal y espiritual" (Catecismo de la Iglesia Católica, 2015, $\left.n^{\circ} 362\right)$.

Ahora bien, lo que hace al humano una persona es la circunstancia de haber sido creada a imagen y semejanza de Dios, tal como surge de Génesis 1 :

$25 \mathrm{E}$ hizo Dios animales de la tierra según su género, y ganado según su género, y todo animal que se arrastra sobre la tierra según su especie. Y vio Dios que era bueno.

26 Entonces dijo Dios: Hagamos al hombre a nuestra imagen, conforme a nuestra semejanza [...].

27 Y creó Dios al hombre a su imagen, a imagen de Dios lo creó; varón y hembra los creó.

El privilegio de la especie Homo sapiens de ser elegida para ser a imagen y conforme a la semejanza de su creador da lugar, en la opinión del filósofo Jean-Marie Schaeffer, a la versión teológica de la tesis de la excepción humana: la afirmación de que, en su esencia propiamente humana, este ser se encuentran exento del orden natural, de lo estrictamente biológico. Así, el humano sería un ser no natural puesto que es irreductible a las otras entidades que integran el mundo (Schaeffer, 2009, pp. 22 y ss.).

Esta "irreductibilidad" se debe a la creencia en que el humano posee una dimensión ontológica en virtud de la cual trascendería la realidad de otras formas de vida y de su propia naturalidad (ser un "ser viviente"). Con otras palabras, bajo esta convicción el humano trasciende las fronteras de lo meramente biológico, espacio en el que se encuentran los demás animales y otros entes. En este camino, la tesis de la excepción humana resulta de una conjunción de cuatro afirmaciones, entre las cuales destacamos:

1. La ruptura óntica en el orden de lo viviente: "el postulado que sostiene que existen dos clases de entes, el hombre, por un lado, y todo el resto, por el otro. Se trata de una concepción segregacionista que plantea una inconmensurabilidad entre el hombre y los otros seres vivientes" (Schaeffer, 2009, p. 26).

2. La particular interpretación del dualismo ontológico: "la tesis según la cual existen dos modalidades del ser, la realidad material, por un lado, y la realidad espiritual, por el otro" (Schaeffer, 2009, p. 26). 
Sobre la relación existente entre la ruptura óntica y el dualismo, cabe decir que la primera presupone una concepción dualista del ser humano, ya que para adherir a la inconmesurabilidad humana respecto del resto de los seres vivos (ruptura óntica) previamente se debe suscribir al dualismo ontológico. Pero, se puede ser dualista sin aferrarse a la ruptura óntica, puesto que afirmar que existen dos modalidades del ser irreductibles (realidad material y realidad espiritual) no implica que se deban distribuir entre dos seres distintos (humanos y no humanos).

No obstante, para la tesis de la excepción humana, el dualismo ontológico resulta reinterpretado como ruptura óntica al interior del Homo sapiens, el cual pasa a estar en sí mismo dividido. Explica Schaeffer:

\begin{abstract}
La tesis de la ruptura óntica no sólo opone dos campos de lo viviente, el de lo humano y el de la animalidad, sino que refuerza esta dualidad en el interior de la concepción del propio hombre, a través de múltiples pares oposicionales -cuerpo/alma, racionalidad/afectividad, necesidad/libertad, naturaleza/cultura, instinto/moralidad, etc.-, todos los cuales de algún modo oponen al hombre a sí mismo. Aún más que la ruptura óntica entre el ser humano y el mundo animal, es esta ruptura interna al propio ser humano lo que pesó sin duda sobre la imagen que nos hacemos de nosotros mismos. (Schaeffer, 2009, p. 25)
\end{abstract}

Particularmente, existe un lazo íntimo en el pensamiento cristiano entre la excepcionalidad humana y la unicidad de Dios. En aquel vínculo, el humano adquiere un estatus trascedente en comparación al resto de los seres, que le permite afirmar al autor:

puesto que el hombre es a imagen de Dios y Dios es trascendente al mundo de las criaturas, aquello por lo cual el hombre es imagen de Dios es también aquello por lo cual él trasciende el mundo de las criaturas (Schaeffer, 2009, p. 23).

Así, la identidad propiamente humana residiría en uno de los dos polos de la división interna del Homo sapiens. Para la versión teológica de la tesis de la excepción humana, la identidad se anclaría en el alma (imagen y semejanza de Dios). Mientras que el otro polo quedaría reducido al sustrato material, el cuerpo animal. Lo dicho encuentra sustento en distintos pasajes del Catecismo cuando aborda la cuestión del cuerpo humano:

El cuerpo del hombre participa de la dignidad de la 'imagen de Dios': es cuerpo humano precisamente porque está animado por el alma espiritual [...]. (Catecismo de la Iglesia Católica, 2015, $\left.n^{\circ} 364\right)$ 
La unidad del alma y del cuerpo es tan profunda que se debe considerar al alma como la 'forma' del cuerpo (...); es decir, gracias al alma espiritual, la materia que integra el cuerpo es un cuerpo humano y viviente; en el hombre, el espíritu y la materia no son dos naturalezas unidas, sino que su unión constituye una única naturaleza. (Catecismo de la Iglesia Católica, 2015, $\left.n^{\circ} 365\right)$

Se desprende de lo anterior que el cuerpo humano es, precisamente, humano gracias a la presencia del alma espiritual. Así, si bien los demás animales son seres vivos que forman parte de la creación, sin embargo no pueden ser considerados personas porque se encuentran impedidos de apropiarse de su propia vida, de poseerse a sí mismos, lo cual solo pueden hacer los individuos de la especie humana:

\footnotetext{
Por haber sido hecho a imagen de Dios, el ser humano tiene la dignidad de persona; no es solamente algo, sino alguien. Es capaz de conocerse, de poseerse y de darse libremente y entrar en comunión con otras personas; y es llamado, por la gracia, a una alianza con su Creador, a ofrecerle una respuesta de fe y de amor que ningún otro ser puede dar en su lugar. (Catecismo de la Iglesia Católica, ob. cit., $n^{\circ} 357$ )
}

Se ve ahora con mayor claridad la genealogía de la personalidad legal: pese al continuo biológico entre los animales de todas las especies demostrado por Charles Darwin, sólo el ser humano sería verdadera persona, sería alguien; y sólo el ser humano sería alguien (una persona) y no algo (una cosa), dado que sólo el ser humano tendría esa dignidad, dignidad ajena a lo corporal, a la biología -siendo por ello inmune a las evidencias de toda teoría científica-, que tendría finalmente un origen divino: el haber sido creado a imagen y semejanza de Dios.

\section{Reconstruir la personalidad desde el antiespecismo}

Con el término especismo se alude al trato discriminatorio basado exclusivamente en la pertenencia a una especie (Horta, 2008, pp. 107-118; Singer, 2018, p. 22; Regan, 2016, p. 186). Al respecto cabe decir dos cosas.

La primera es recordar, releyendo a Darwin, que "especie" es una mera categoría, es un concepto, una herramienta analítica, y no una ontología. Además, se trata de una categoría relativamente arbitraria que se utiliza por razones de conveniencia para distinguir seres que son relativamente diferentes y agrupar a otros relativamente similares (7). Y que, si ni el género 
ni la población son categorías binarias, sino que debe hablarse más bien de continuos, y dichas categorías no tienen entidad ontológica, sino que se trata de construcciones culturales, no cabe cambiarse de anteojos a la hora de analizar esta otra categoría, la de especie, y apelar a lo "natural" de la misma. ¿Cómo seguir afirmando, contra toda la teoría científica, y de la mano de toda la teología, que hay un claro y natural abismo entre los Sapiens, por un lado, y por el otro una enorme categoría en la que se amontona a seres tan diferentes entre sí como delfines y hormigas, orangutanes y comadrejas, palomas y leopardos, vacas y ratones?

La segunda cuestión es preguntarse cómo la especie podría ser una razón válida para encerrar, torturar y matar a seres sintientes. ¿Qué relación podría existir entre el hecho de pertenecer a una especie determinada (más bien entre el hecho de no pertenecer a una especie determinada: Homo sapiens) y el ser (o no) candidato a los derechos básicos a la libertad, integridad psicofísica y a la vida? El criterio central aquí es la relevancia moral de las características fácticas que se consideran. $Y$ así como (en las palabras de los tratados de derechos humanos) la raza, el color, el sexo, etc., no son razones para denegar estos (y otros) derechos básicos, la especie tampoco puede serlo; la especie es, con las restantes categorías, una categoría sospechosa (8).

Es cierto que hay características físicas o cognitivas que podrían ser relevantes para gozar de determinados derechos. Por ejemplo, es razonable sostener que debo tener una determinada edad y desarrollo madurativo para tener derecho a votar; pues, si no pudiese votar, no tendría un interés en votar y no sería razonable reclamar un derecho al voto. Por tal motivo nadie reclama el derecho al sufragio de los niños de dos años de edad ni igual derecho para los orangutanes adultos (que tienen una inteligencia superior a los humanos de dos años de edad). Sin embargo, otras características no tienen relevancia moral alguna a la hora de reconocer derechos fundamentales: hoy nadie diría que una persona (humana) tiene que tener más de un determinado coeficiente intelectual para gozar del derecho a la libertad, a no ser víctima de torturas y a la vida. ¿Por qué? Pues para gozar de la libertad, de la integridad psicofísica y de la vida, sólo se requiere contar con un sistema nervioso central, con conciencia y poseer experiencias subjetivas (9).

¿Cómo sería una teoría de la personalidad desde una mirada antiespecista? Como primera medida, esa teoría no acordaría ni negaría el carácter de persona a los individuos sólo por su pertenencia o no pertenencia a una especie biológica. A su vez, una teoría antiespecista de la de la personalidad debería rechazar una métrica supremacista, esto es una posición que acuerde mayores personalidad y derechos a los individuos con mayores habilidades, y menores o ninguna personalidad y derechos a seres con menos habilidades (10). 
Según alcanza a verse a partir de lo dicho en los apartados previos, cuando se habla de persona y de personalidad puede estar aludiéndose a distintas cosas, dependiendo ello principalmente del contexto. Así, suelen distinguirse entre los sentidos metafísico, moral, jurídico y coloquial del término persona (Dennett, 1989; Horta, 2011, pp. 55-83). De cualquier modo, pese a las diferencias, existe una vinculación entre las distintas acepciones de este término: normalmente se postula que sólo son personas los seres racionales y autoconscientes (sentido metafísico), que sólo estos individuos son capaces de tener motivaciones morales y ser moralmente responsables (sentido moral), y de adquirir derechos y contraer obligaciones (sentido jurídico); y que -se afirma- dado que sólo los seres humanos reunirían estas condiciones, el término persona sería sinónimo de ser humano (sentido coloquial) (Dennett, 1989, p. 11).

Más allá de este trazo grueso inicial, los autores no se ponen de acuerdo sobre qué condiciones específicas permiten o impiden que un ser sea una persona. En otros términos, no existe consenso alguno sobre cuáles serían las condiciones necesarias y suficientes de la personalidad. (Rawls, 1993, pp. 557 y ss.; Dennett, 1989). Pese a existir un acalorado debate al respecto, llamativamente, la mayoría de los autores sin embargo coincide en que todos los seres humanos y sólo los seres humanos serían personas. (Horta, 2011, p. 62).

Las posiciones especistas resuelven las importantes diferencias que existen entre las distintas visiones de la personalidad a partir de atajos que tienen un recorrido muy similar. Tal vez el ejemplo más famoso sea el de John Rawls, quien en su Teoría de la Justicia dice al ocuparse de este tema:

Tenemos que considerar todavía a qué clase de seres se deben las garantías de la justicia. $[\ldots]$ La respuesta natural parece ser la de que son precisamente las personas morales las que tienen derecho a una justicia igual. Las personas morales se distinguen por dos características: la primera, que son capaces de tener (y se supone de adquirir) un sentido de su bien (expresada por un proyecto racional de vida); y segunda, que son capaces de tener (y se supone de adquirir) un sentido de justicia, un deseo normalmente eficaz de aplicar y de actuar según los principios de justicia, por lo menos hasta cierto grado mínimo. $[\ldots]$

Vemos, pues, que la capacidad de personalidad moral es una condición suficiente para tener derecho a una justicia igual. [...] Si la persona moral constituye también una condición necesaria es cuestión que voy a dejar de lado. Doy por supuesto que la capacidad de un sentido de la justicia es poseída por la abrumadora mayoría de la humanidad, y, por consiguiente, esta cuestión no plantea un grave problema práctico. [...] Sería un grave error 
suponer que siempre se satisface la condición suficiente. Aunque la capacidad sea necesaria, sería una imprudencia, en la práctica, reducir la justicia a esta base. El riesgo para las instituciones justas sería demasiado grande.

Es conveniente subrayar que la condición suficiente de la justicia igual, es decir, la capacidad de personalidad moral, no es imprescindible, en absoluto. Cuando alguien carece de la potencialidad requerida, ya sea por nacimiento o por accidente, esto se considera como un defecto o como una privación. No hay raza ni grupo reconocido de seres humanos que carezca de este atributo. [...]

[...] Todo lo que tenemos que hacer es elegir una condición específica (como luego diré) y dar una justicia igual a los que la satisfagan. Por ejemplo, la condición de estar en el interior de un determinado círculo es una condición específica de unos puntos del plano. Todos los puntos que se encuentran dentro de este círculo tienen esta propiedad, aunque sus coordenadas varíen dentro de una cierta extensión. $Y$ tienen esta propiedad en un grado igual, porque ningún punto interior al círculo es más o menos interior a él que cualquier otro punto interior. [...]

Pero, naturalmente, nada de esto es, literalmente, una argumentación. No he formulado las premisas de las que se sigue esta conclusión [...]. [L]os que se ven privados de personalidad moral, más o menos permanentemente, pueden presentar una dificultad. No puedo examinar aquí este problema, pero creo que la descripción de la igualdad no se verá materialmente afectada. (Rawls, 1993, pp. 557 y ss.)

Resumiendo, de acuerdo a Rawls: La personalidad moral sería una condición suficiente para tener derecho a una justicia igual. "Si la persona moral constituye también una condición necesaria es cuestión que voy a dejar de lado", ya que "la capacidad de un sentido de la justicia es poseída por la abrumadora mayoría de la humanidad, y, por consiguiente, esta cuestión no plantea un grave problema práctico." Ello pese a que un número de individuos que multiplica muchas veces a toda la especie humana podría ser candidato a una justicia igual, y a que asimismo "Sería un grave error suponer que [con los seres humanos] siempre se satisface la condición suficiente." Y que, "aunque la capacidad sea necesaria, sería una imprudencia, en la práctica, reducir la justicia a esta base."

La aplicación de estas ideas, como se ve, y salvo que se recurra al recurso dogmático de incluir y excluir individuos trazando líneas que forman círculos que dejan puntos adentro y afuera del mismo (pues, "naturalmente, nada de esto es, literalmente, una argumentación", según reconoce Rawls), no otorgaría derechos a esta igual justicia a aquellos seres humanos "que se ven privados de personalidad moral, más o menos permanentemente", casos que "pueden presentar una dificultad", pero que -dice para finalizar este autor- "No puedo examinar aqui". 
Una ética antiespecista no admite estas diagonales y pases de magia. Frente al problema de determinar cuáles son las condiciones necesarias y suficientes para la personalidad, una posición antiespecista verá sólo dos alternativas: por un lado adoptar una mirada estricta, que requiere características elevadas de agencia y reciprocidad para otorgar el carácter de persona -con independencia de la especie a la que pertenezcan los seres en cuestión-, mirada que encarna una ética supremacista y de estrechamiento del círculo de consideración moral; o bien tener una mirada amplia, que no requiere más que sintiencia, conciencia y poseer experiencias subjetivas -que hagan posible a los individuos en cuestión gozar de los derechos fundamentales- para acordar personalidad y los derechos básicos que se asocian a la misma, ampliando el círculo de consideración moral desde una ética de cuidado o apoyada en las nociones de vulnerabilidad, necesidad e intereses (Kymlicka, 2017, pp. 1-30).

La primera de las alternativas recién mencionadas no sólo amenaza con quitar el carácter de personas -y los derechos más básicos que se asocian a la misma- a los humanos que carecen de esas exquisitas habilidades (menores de edad, individuos con condiciones congénitas, adquiridas o degenerativas que los limitan física o cognitivamente; esto es, nada menos que toda la especie humana en algún momento de su vida y una gran parte de los miembros de esta especie durante toda su vida). Como señaló agudamente Daniel Dennett, justamente en los casos que más importan, cuando evaluamos la responsabilidad moral y legal de los humanos frente crímenes atroces y acciones inexplicables, y rastreamos la causa de estos actos en condicionantes sociales, en una crianza represiva, en una infancia violenta y miserable, encontramos al mismo tiempo las razones para dudar de la racionalidad, de la agencia autónoma, de la libertad y -en definitiva -de todo lo que hace personas a las personas (Dennett, 1989, p. 36).

La segunda alternativa no sólo es más empática, inclusiva y coherente con la máxima que llama a otorgar mayores derechos y consideración moral a quién más vulnerable es. También es más realista en torno al lugar que ocupa la especie humana en el planeta y en el cosmos, alejándose de los delirios megalómanos de los textos sagrados de las religiones judeocristianas.

\section{Algunas conclusiones provisorias}

Para finalizar, enumeramos algunas de las conclusiones a las que arribamos por el momento:

1. El humanismo antropocéntrico es hijo no reconocido del teocentrismo. 
2. Genealógicamente, el humanismo antropocéntrico se apoya sin decirlo sobre una visión supremacista del sujeto, de quien es un sujeto y de quien es considerado un objeto, una cosa. El Derecho adopta de modo acrítico esta forma de humanismo.

3. Pueden rastrearse y luego seguirse dos variantes totalmente opuestas de los derechos morales fundamentales (tal vez una denominación preferible a la de derechos humanos) y de la personalidad. Una variante supremacista, que es la original y canónica, que construyó la dignidad de los individuos que cuentan a partir de la inferioridad de otros seres, a los que pisoteó, degradó y utilizó (como lo hizo con mujeres, habitantes originarios de América, esclavos, homosexuales, personas con diversidades físicas y cognitivas, y con los demás animales). Una variante no supremacista, que por ejemplo desde una ética del cuidado, cuanto mayor vulnerabilidad y otredad, más -y no menos- consideración y derechos confiere (Kymlicka, 2017, pp. 1-30). Esta variante necesariamente debe ser antiespecista y acordar personalidad moral y legal a los demás animales.

Notas

(1) Lo cual no está desvinculado de la fuerte injerencia que esta iglesia aún conserva en los asuntos públicos y con el multimillonario financiamiento estatal que recibe, por ejemplo, a través de subsidios y exenciones impositivas a las escuelas religiosas, lo que importa un incentivo para la educación religiosa.

(2) En el mismo libro al mismo tiempo se ordenar conquistar y matar a todos los pueblos vecinos, secuestrando a niños y doncellas. Ver, entre otros pasajes: Éxodo 32:27-28:

$27 Y$ él les dijo: Así ha dicho Jehová, el Dios de Israel: Poned cada uno su espada sobre su muslo: pasad y volved de puerta á puerta por el campo, y matad cada uno á su hermano, y á su amigo, y á su pariente.

$28 Y$ los hijos de Leví lo hicieron conforme al dicho de Moisés: y cayeron del pueblo en aquel día como tres mil hombres.

(3) Ver nota 2.

(4) El alma será además, luego de Darwin, el último bastión de la diferencia que se quiere sostener entre los humanos y los demás animales (Rachels, 1990). Véase lo que se dirá al respecto en el punto 2 del capítulo III.

(5) El art. 30 del CC, establecía: "Son personas todos los entes susceptibles de adquirir derechos, o contraer obligaciones".

(6) Dejamos asentado que en la historia no se ha utilizado siempre la voz persona, sino también el término griego u̇móotaoıs (hipóstasis), que hoy en día, en el lenguaje teológico, es 
equivalente a persona. No obstante, esta actual equivalencia entre persona e hipóstasis es el fruto de extensas discusiones y conflictos históricos derivados tanto de la diversa concepción teológica entre los padres griegos (oriente) y latinos (occidente), como de la falta de entendimiento lingüístico entre ellos respecto del sentido que cada uno les atribuía a aquellas palabras. Véase: Ruta, 1986, t. II, vol. 1, p. 221 y ss.

(7) Explica el naturalista: inglés "Entiendo al término especies como uno adoptado arbitrariamente, por razones de conveniencia, que se da a un grupo de individuos que se asemejan entre si". (Darwin, 1992, p. 70).

(8) La especie debería ser considerada, junto con la raza, el sexo, la religión y las capacidades físicas, una categoría sospechosa en los términos de los tratados y la jurisprudencia del sistema interamericano de derechos humanos, lo cual genera una presunción de discriminación y una inversión de la carga de la prueba en contra de quien pretenda tratar desigualmente por características que carecen de relevancia moral como las mencionadas (Suárez, 2017, p. 72).

(9) Esto muestra asimismo que el antiespecismo no está comprometido con la defensa de la vida en sí misma, ni habla de la sacralidad de la vida. Una antiespecista dirá, luego de todo lo anterior, que un embrión de dos, cinco, nueve, catorce semanas (un embrión humano o de cualquier otra especie con igual desarrollo neurológico), al no ser un individuo sintiente, al carecer del aparato neuronal que permite tener experiencias subjetivas aunque sean básicas, no tiene derecho a la vida ni a la integridad psicofísica. Podría incluso pensarse que en verdad son las posiciones especistas las que ingresan en terrenos pantanosos aquí: si la especie Homo sapiens es una categoría moralmente relevante, al punto de ser la bisagra que otorga y quita derechos a distintos individuos, el especista camina en la delicada frontera que, en el debate sobre el derecho al aborto, limita con las discusiones sobre el comienzo de la vida, si vida es igual a personalidad y si persona es igual a ser humano.

(10) Sunaura Taylor distingue entre las nociones de inhabilidad y discapacidad. Con la primera identifica a la particular encarnación de la imposibilidad o dificultad de un cuerpo de realizar algo. La discapacidad es el resultado de una forma de discriminación social hacia las personas con algún tipo de inhabilidad (Taylor, 2008, min. 5' a 5:30'). En la idea de lo superior y lo inferior, de lo normal y lo anormal, de la capacidad y la incapacidad, puede encontrarse una errada comprensión de la teoría de la selección natural (inconvenientemente recordada con el nombre de "teoría de la evolución"), más parecida a la defendida por Lamarck, que pensaba que existía una evolución lineal, ascendente y teleológica, y alejada de la que finalmente adquirió consenso científico, elaborada por Darwin, que tiene forma de árbol o senderos que se bifurcan y carece de un componente teleológico, siendo la adaptación de las especies precisamente eso, una adaptación a circunstancias aleatorias que cada una de éstas debieron 
enfrentar y no una evolución (Rachels, 1990, pp. 64-65). Ciertamente podría pensarse en un conjunto de características evolutivamente "superiores": mejores visión y audición, mayor habilidad corporal, mayor velocidad, mayor inteligencia. Si bien es innegable que estas características son deseables para enfrentar a una porción de los desafíos que presenta la vida (la competencia entre los individuos por los recursos, la disputa entre predadores y presas), no todos los obstáculos que enfrentamos tienen la misma lógica ni requieren de este tipo de habilidades. Para enfrentar toda otra serie de enormes desafíos como los que a lo largo de la evolución presentaron el medioambiente, el cambio climático, los virus y las bacterias, las características señaladas inicialmente no tuvieron ni tienen hoy ninguna utilidad. Considérese por ejemplo la inmunidad genética a distintos virus y bacterias que tienen algunos humanos (recientemente se descubrió que algunas personas tienen un gen que las hace inmunes al Virus de Inmunodeficiencia Humana-VIH). ¿Serían entonces estos humanos los capaces y quienes no tienen esta mutación genética incapaces? (Suárez, 2017, p. 76, nota 38).

\section{Bibliografía}

Agustín de Hipona. (1956). Obras de San Agustín en edición bilingüe: Tratado sobre la santísima trinidad. Segunda edición, primera versión española, introducción y notas de Fr. Luis Arias O.S.A. Madrid: La Editorial Católica S.A.

Alterini, Jorge H. y Alterini, Ignacio E. (2016). Opinión al art. 19 en la 1aㅡ edición. En Alterini, Jorge H., (Dir. General) - Alterini Ignacio E. (Coord.) - Tobías, José W. (Dir. de tomo), Código Civil y Comercial comentado: Tratado exegético. $2^{2}$ edición actualizada y aumentada. Argentina: La Ley.

Adams, Carol. (2016). La política sexual de la carne. Madrid: Ed. Ochodoscuatro.

Braidotti, Rosi. (2013). The Posthuman. Great Britain: Polity Press.

Catecismo de la Iglesia Católica. (2015). Buenos Aires: Conferencia Episcopal Argentina Oficina del libro.

Darwin, Charles. (1992). El origen de las especies. Traducción José P. Marco. España: Planeta.

Dennett, Daniel. (1989). Condiciones de la Cualidad de Persona. Cuadernos de Crítica 45. Universidad Nacional Autónoma de México.

Horta, Óscar. (2011). La cuestión de la personalidad legal más allá de la personalidad humana. Isonomía: Revista de Teoría y Filosofía del Derecho, 34. 
(2008). Términos básicos para el análisis del especismo. En González, Marta I. -Riechmann, Jorge - Rodríguez Carreño, Jimena - Tafalla, Marta (coords.), Razonar y actuar en defensa de los animales. Madrid: Los libros de la catarata.

Kymlicka, Will. (2017). Human Rights without Human Supremacism. Canadian Journal of Philosophy, publicación online del 13/10/2017.

Pace, Edward. (1910). Unión hipostática. The Catholic Encyclopedia. Nueva York: Robert Appleton Company. Vol. 7. Recuperado de http://www.newadvent.org Lcathen/07610b.htm el 7/02/2019

Rachels, James. (1990). Created from Animals. The Moral Implications of Darwinism. Oxford University Press.

Rawls, John. (1993). Teoría de la justicia. México: Fondo de Cultura Económica.

Regan, Tom. (2016). En defensa de los derechos de los animales. Traducción Ana Tamarit, Revisión Técnica Gustavo Ortiz Millán. México: Fondo de Cultura EconómicaUniversidad Nacional Autónoma de México-Instituto de Investigaciones Filosóficas Programa Universitario de Bioética.

Ruta, Juan C. (1986). La vida Trinitaria. La Plata: Fundación Instituto de Teología. T. II, vol. 1.

Schaeffer, Jean-Marie. (2009). El fin de la excepción humana. Traducción de Víctor Goldstein. Buenos Aires: Fondo de Cultura Económica.

Singer, Peter. (2018). Liberación animal: El clásico definitivo del movimiento animalista. Edición actualizada. España: Taurus.

Suárez, Pablo. (2017). Animales, Incapaces y Familias Multi-especies. Revista Latinoamericana de Estudios Críticos Animales. Año IV, Vol. II.

Taylor, Sunaura. (2011). Beasts of Burden: Disability Studies and Animal Rights. Qui Parle. Vol. 19, No. 2.

(2008). Entrevistada por Judith Butler. La Vida Examinada. Recuperado de http://https://www.youtube.com/watch?v=kOHZaPkF6qE el 9/7/2019

Tobías, José W. (2016). Glosa al art. 19. En Alterini, Jorge H., (Dir. General) - Alterini, Ignacio E. (Coord.) - Tobías, José W. (Dir. de tomo), Código Civil y Comercial comentado: Tratado exegético. $2^{\mathrm{a}}$ edición actualizada y ampliada. Argentina: La Ley. T. I. 